\title{
Pantun with Quantum Learning Model as A Media Language Learning
}

\author{
Sabhan \\ Lambung Mangkurat University \\ Banjarmasin, Indonesia \\ sabhansaberi@gmail.com
}

\begin{abstract}
Pantun is an original literary of Indonesia. Almost all people of Indonesia know and love the pantun. Many folk songs which are dominated pantun. Not even a little bit of pop song and dangdut modern using pantun as poets or their contents. As a work of art or literature, pantun very precisely made media learning a number of subjects. It's been proven multiple times, it can increase creativity and liveliness of the students in the teaching-learning process and improve the learning results of the elementary school students (elementary) and secondary school (high school), and the College's to the new knowledge. Moreover, if it was sung or conveyed by tone or rhythm track that engrossing.

Using pantun as a learning medium in school is the embodiment of the contextual approach to the quantum learning model. Quantum learning model that uses pantun as its media, learning will always be fun and excitement of learning students will never recede.

Pantun that used learning media, of course, was already created a tone or song. There are a number of tone or songs that can be used as a basis of pantun for learning in schools and colleges, namely the Asese tone and Rasa Sayange.

This will be done easily if the teachers and lecturers want to learn how to create and utilize pantun as the quantum learning model. With the utilization pantun as the learning media in schools and colleges, teachers/lecturers with pupils become more familiar. This kind of learning is not limited only to the classroom but it can be done anywhere or the open place. In addition, pantun as the nation's favorite work we will everlasting and develop in accordance with the progress of the times.
\end{abstract}

Keywords_-pantun; tune; quantum learning model

\section{INTRODUCTION}

Pantun as part of a literary work is the old indigenous culture Indonesia. Pantun has significance. In situ tecermin of the soul and the nature of the original nation of Indonesia. Almost on every art, there is pantun Indonesia area, especially in the regions.

Pantun being propounded here is the pantun consists of four rows: the first row and second called sampiran (introduction), the third and fourth lines are called content; There are his ab-ab, aa-aa. From the beginning of pantun tasty heard and easy to understand, the even poetic idea is with beauty that sometimes veiled and sometimes open. In other words, the beauty of the (aesthetically) it's hidden, move, and embedded in the heart.

Pantun, also known as an old poem. In it contained a variety of culture in accordance with the origin of the pantun.
For example, if your load from Borneo, Borneo's culture; If you're from Padang, Padang culture contains; If you're from Malaysia, contains a culture of Malaysia.

Pantun were not different from the language of Indonesia is the legacy of our predecessors. If you're generated by the literati, Indonesia language generated by our fighters who valiantly have vowed in front of the colonist on October 28, 1928. They vowed, "we sons and daughters of Indonesia, respect the language of unity, the third language of Indonesia (item Sumpah Pemuda. Indeed we cannot deny that our youths prefer to speak Indonesia Gaul than Baku, although in official places such as a school or college. In fact, they tend to feel ashamed or deemed not slang if Indonesia-speaking properly. More of concern is not a few teachers and professors who also likes to speak Indonesia gaul was. What our actions as the heir who has the next heir?

If a teacher has mastered the pantun, either taught or makes it, he will easily be able to teach a wide range of other subjects, especially language (Indonesian), let alone with the application of quantum learning model (quantum teaching) [1]. Refference [2] said that almost the same quantum learning model with a Symphony. Thus, language teaching will be much more interesting if presented with the pantun song. The following is an example of pantun songs (and not the numbers) of a region in Indonesia [3].

\section{TUNE OF SING}

A. Asese

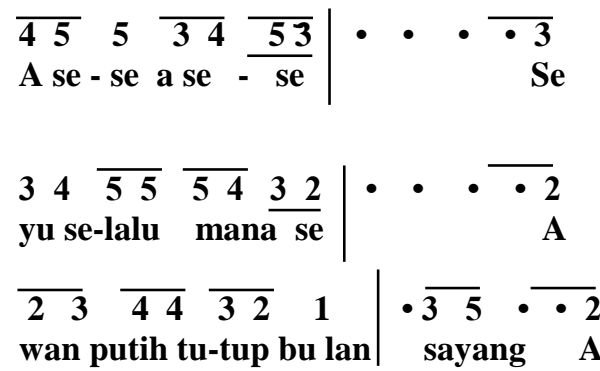

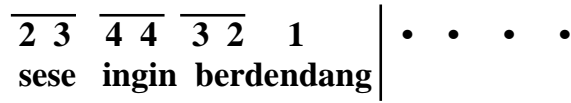

B. Asese with Pantun

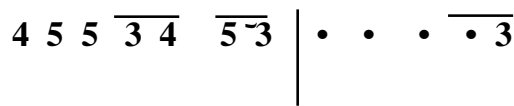


Beli baju di ko-ta Batu

$\mathbf{P i}$

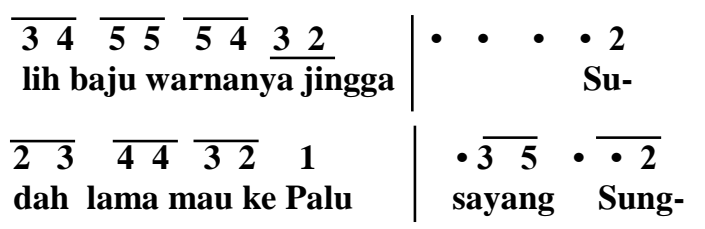

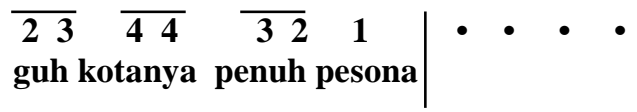

\section{LEARNING MATERIALS}

A. The position of the Indonesian Language

Semua bangsa punya bahasa

Sebagai syarat negara merdeka

Bahasa Indonesia bahasa negara

Kata UUD empat lima

'All Nations have a language

As a condition of independent States

Indonesian Language the language of the country

The word four-five Constitution'

All students Indonesia certainly never taught about the position of the Indonesia language [4]. However, whether they always remember it? For more inherent in their memories, the delivery with your be more fitting sentence compared with the news. So, just enter or adjust the tone of the song against a pantun to be delivered.

B. Recommending the use of effective sentences

Ke kota Palu naik pesawat

Singgah sebentar di Jakarta

Kalau engkau ingin selamat

Hati-hati dalam berbahasa

'To the city of Palu fly

A short stopover in Jakarta

If you want to survive

Caution in speaking'

Masakan Padang sambalnya pedas

Enak dimakan dengan ikan

Jika bicara, singkat dan jelas

Jika lama, akan membosankan

'Padang cuisine traditional spicy

Delicious ate with fish

If a short talk, and clear
If long gets boring'

We often hear people use the same word is not in place, but the sincerity is the word with. For example:

Bahasa Indonesia Bahasa budaya

Kalimat efektif Sangat berguna

Bukan saya sama dia

Tapi saya dengan dia

'Indonesian language is language culture

Effective sentences are very useful

Not me same he

But I'm with him'

Many people are obsessed with the cup (hopefully not cupkissing), including students in the naming contest trophy or Cup competitions, such as the trophy/Cup of Rector. Pantun:

Setiap orang Punya sikap

Tujuan bertanding memecah rekor

Mereka menyebut "Rektor Cup"

Ayo gunakan "Trofi Rektor"

'Everyone's got an attitude

The goal of a match broke the record

They call "Rector's Cup"

Let's use the "Rector's Trophy"'

Not the least of our society who call the number zero (0) with an empty, whereas blank means none (of the contents). Pantun:

Pergi Ke kampus membawa tustel

Tustel dibuka gambarnya gosong

Angka pertama nomor ponsel

Namanya nol bukanlah kosong

'Go to the campus carrying a camera

Camera opened his image charred

The first digit mobile phone number

The name zero is not empty'

Pulau Senor jauh di mata

Tong kosong nyaring bunyinya

Kalau nol bundar angkanya

Kalau kosong, tak ada isinya

'The Senor island is in the eye of

A loud sound of empty kegs

If the zero round numbers 
If empty, no contents'

Many people who call list present or presence with abstentions or absences. But they know that absence means absent and attendance means the list is not present. Pantun:

Yang kuliah namanya mahasiswa

Yang mengajar namanya dosen

Jika hadir dalam acara

Carilah presensi bukannya absen

'College student's name

Teaching lecturer name

If attending the event

Look for presensi instead of the absent'

There are also people who like to reduce the letter of a word that is already correct, as only writing. Pantun:

Cuaca panas di tengah kota

Enak sekali minum es

Jika saja disebut aja

Itu namanya korupsis

'Hot weather in the middle of the city

Delicious drink ice

If only called aja

It's called corruption s'

There are also people who like to add the letter on a word that is already correct, as said just being sure. Pantun:

Bahasa bukanlah mainan

Bukan pula barang sulap

Kalau cuma dikatakan cuman

Itu bisa disebut mark up

'Language is not a toy

Neither magic items

If it "cuma" said "cuman"

It can be called mark up'

That is also very much said (and written) is the word or agreeing with digantinya get along okay or ACC.: Pantun

\section{Ikan satu dibagi tujuh \\ Letakkan lauk di atas nasi \\ Kalau setuju katakan setuju \\ Janganlah oke atau acc}

'Fish one split seven

Put the dish over rice

If agreed, saying agree

Be not okay or acc'

There is also the season of the project with the project that should use the word workshop, which he changed into a workshop. Pantun:
Nonton film dalam bioskop

Filmnya dari India

Guru dan dosen suka workshop

Padahal yang benar lokakarya

'Watch movies in theaters

The film from India

Teachers and professors love workshop

Whereas the right workshop'

Most teachers and professors there who asked his pupils to hand but were brandishing foster's hands. Pantun:

Kota Palu banyak sawah

Di Samarinda ada ikan pesut

Angkat tangan artinya menyerah

Acungkan tangan yang dimaksud

'City of Palu many rice fields

There are fish porpoises

Raise your hand means giving up

Waved a hand is'

There are people who like not guilty say the guns ' but he knew that the right is not. Pantun:

Bola mata bermacam warna

Usia muda makin tampak

Kalau tidak dikatakan ngga'

Itu pertanda kurang bijak

'Eyeball various colors

Young age makin looks

If not said guns'

It was the harbinger of less wise'

That's just some of the words that are frequently used in everyday life. There are many more words that shouldn't have to be used because there is a raw form. We certainly can easily register. If we've found the wrong words, certainly also make pantun easily.

\section{The Tune of Another Song}

If it's been clever with the song Asese, but would like to replace it with another tune. It can be done with certain areas, such as Maluku following folk songs.

\section{Rasa Sayange}

\begin{tabular}{llll|llll}
$\overline{34}$ & 5 & 5 & $\mathrm{i}$ & $\overline{76}$ & $\overline{56}$ & $\overline{34}$ & 5
\end{tabular}

Rasa sa ya-nge rasa sayang sa ya-nge

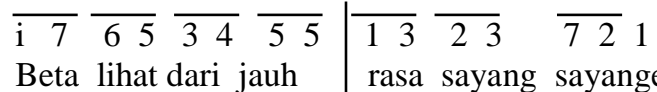

In addition, not only the field of language can be made pantun, but almost all fields of science. For example, for a joke, we can use the following pantun. Example:

Jika engkau punya keris 
Jangan simpan dalam saku Jika bisa berbahasa Inggris Apa artinya "I love you"

'If you have a keris

Do not store in pocket

If it can be the English

What does it mean I love you'

\section{HOW TO LEARNING}

In order to tone or rhythm essentially unchanged/off once, after delivering the content material, back to the basic tone (asese). How to learn the language with your media there are three kinds, such as the following.

\section{A. One-way}

Any learning must, of course, be prepared cooking. Similarly to teach language with media pantun [5]. The teacher should prepare such a pantun material above. It also requires a mastery of how to make your subject matter, let alone the language very much [6]. However, if we have become accustomed to making the pantun, everything becomes easy. Here the teacher more acts as the giver of the examples to be listened to by their students. Teachers sing the pantun in front of a class of its own.

\section{B. Two-way}

If a one-way learning was implemented, it would be easier to do a two-way (pantun reciprocated). Pantun prepared could come from teachers, can also be made together, even it would be great if the pantun, based on respective ideas. After all the students have a pantun, teachers act as leader of the Symphony. He gave examples in advance how to sing the pantun. Thus, the class became alive and students more interested in learning.

\section{Cooperative}

Teachers can act as observers only, while all the students asked to practice reciprocated pantun with pantun each of the already-selected teachers. Alternately they sang pantun with a tone that's been determined together.

\section{CONCLUSION}

The use of the pantun as media language learning with a model of quantum learning, sure the results will be better if compared to just talk. In addition, it is not just a matter of ' language the pupils, but also pantun. So, language teaching with media pantun apart wasn't boring, also became a means of preservation and development of the pantun itself.

\section{REFERENCES}

[1] DePorter, Bobbi, 2004. Quantum Learning: Mempraktikkan Quantum Learning di Ruang-Ruang Kelas.Terjemahan Ary Nilandari. Bandung: Penerbit Kaifa.

[2] A'la, Misftahul. 2010. Quantum Teaching. Jakarta: Penerbit Diva Press.

[3] Effendi, Rustam \& Sabhan. 2007. Sastra Daerah. Banjarmasin: PBSFKIP Unlam.

[4] Partin, Ronald L. 2009. Kiat Nyaman Mengajar di dalam Kelas. Jilid 1 \& 2. Terjemahan Ursula Gyani Buditjahja. Jakarta: PT Indeks.

[5] Sadiman, Arif S., dkk. 2008. Media Pendidikan (Pengertian, Pengembangan, dan Pemanfaatannya). Jakarta: Raja Grafindo Persada.

[6] Stanislavsky, Konstantin. 2006. My Life in Art. Penerjemah Max Arifin. Malang: Pustaka Kayutangan. 